\title{
Molecular identity of the unique symbiotic dinoflagellates found in the bioeroding demosponge Cliona orientalis
}

\author{
Christine H. L. Schönberg*, William K. W. Loh \\ Centre for Marine Studies, The University of Queensland, St. Lucia, Queensland 4072, Australia
}

\begin{abstract}
Symbiodinium spp. are well-known symbionts of corals. A number of key species of bioeroding sponges also contain intracellular dinoflagellate symbionts, but little is known about this relationship. The origin and identity of sponge symbiotic dinoflagellates is unresolved since their discovery in 1964. Symbiotic bioeroding sponges can invade and kill live corals. If the sponges acquire symbionts during this process, they may act as refuges for vulnerable coral symbionts, as bioeroding sponges appear to be more resistant to thermal bleaching than most corals. To test this hypothesis, pairwise tissue samples from the common brown bioeroding sponge Cliona orientalis Thiele, 1900 and from abutting corals were taken. Samples were obtained from 3 disparate regions of northeastern Australia, extending over more than $1300 \mathrm{~km}$. The genetic identities and population diversities of Symbiodinium from sponges and respective host corals were surveyed using 28S RNA gene sequences. Results suggest that $C$. orientalis consistently harbours the same clade of symbionts, even in very different environmental conditions. However, populations of sponge Symbiodinium did not appear to be genetically connected between the sampled regions, implying maternal transmission of the symbionts. Furthermore, the sponge zooxanthellae were different to those found in corals. We thus rejected the hypotheses that (1) the sponge acquires its symbionts from invaded corals under normal conditions and (2) that it may offer a refuge to coral symbionts. Symbionts from C. orientalis were closely related to, but distinct from symbionts of soritid foraminiferans, and are likely to belong to a new subclade of G-type dinoflagellates.
\end{abstract}

KEY WORDS: Symbiosis $\cdot$ Molecular identity $\cdot$ Dinoflagellata $\cdot$ Symbiodinium $\cdot$ Porifera $\cdot$ Cliona orientalis · Great Barrier Reef

\section{INTRODUCTION}

Animal-plant symbioses belong to the most physiologically efficient and specialized associations presently known. Nevertheless, symbioses between marine invertebrates and photosynthetic dinoflagellates can be found over a wide range of taxa, including cnidarians, sponges, molluscs and polychaetes (e.g. Davies 1992). Dinoflagellate symbionts were originally observed in cnidarians and were named zooxanthellae or Symbiodinium (Kawaguti 1944, Freudenthal 1962). To date only a few Symbiodinium species have been fully described (Trench 1997). However, a high molecular diversity exists, resulting in the identification of numerous phylotypes within 8 genetic clades $(\mathrm{A}, \mathrm{B}, \mathrm{C}$, D, E, F, G and $\mathrm{H}_{\text {; }}$ Baker 2003, LaJeunesse et al. 2003, Pochon et al. 2004).

Dinoflagellate symbiosis have been investigated extensively for cnidarians and molluscs, but they are not as well understood in sponges. The first spongeSymbiodinium association was observed in 1964 in the bioeroding sponge Cliona viridis (Schmidt, 1862) (Sarà \& Liaci 1964). Only recently have more studies followed. Apart from isolated reports of free-living sponge species with symbiotic dinoflagellates (Haliclona sp., e.g. Garson et al. 1999; Cinachyra tarentina: 
Scalera-Liaci et al. 1999), the association prevails in the Clionaidae, the most diverse and dominant group of bioeroding sponges. Not all Clionaidae contain zooxanthellae, and zooxanthellate bioeroding sponges appear to be closely related and have been grouped in the 'Cliona viridis species complex' (Sammarco et al. 1987, Rosell \& Uriz 1991, Schönberg 2002). Its members can develop into large colonies spreading over several square metres. They are very good space competitors. Some are known to live in the direct vicinity of live coral, eventually overgrowing, displacing and killing it (Vicente 1978, Hill 1999, Schönberg \& Wilkinson 2001). Several authors observed an increase of bioeroding sponges on disturbed coral reefs, and reported that the sponges can locally reach epidemic status due to changed environmental conditions (Rose \& Risk 1985, Rützler 2002).

The close association between bioeroding sponges and corals poses the question whether the sponges are able to obtain symbionts from neighbouring zooxanthellate organisms (horizontal transmission), or whether populations of Symbiodinium are transmitted by the parent sponge (maternal or vertical transmission). It could also be a combination of both. Previous studies on other Cliona spp. came to different conclusions. Hill \& Wilcox (1998) experimentally bleached $C$. varians. After recovery, the sponge was found to contain zooxanthellae identical to those of a sympatric anemone, suggesting that horizontal transmission may be possible under extreme conditions. However, in the Mediterranean C. viridis (sensu Rosell \& Uriz 1991) dinoflagellates appear to be passed on by the parent sponge. Mariani et al. $(2000,2001)$ reported that zooxanthellae were found in follicular cells of the oocyte and in aquarium-reared sponges, which were kept in filtered seawater and had no contact with other zooxanthellate organisms. Even though it is possible that dual modes of symbiont acquisition may exist in Cliona spp., current evidence from the Mediterranean suggests that vertical transmission is likely to be the rule.

The origin of sponge symbionts is of special interest in the context of climate change. Zooxanthellate bioeroding sponges have been observed to be surprisingly resilient to bleaching phenomena, and have been noted to survive, where other zooxanthellate invertebrates bleach and die or suffer sub-lethal damage (Vicente 1990, Schönberg \& Wilkinson 2001). Nevertheless, the taxonomic affinity of original populations of sponge zooxanthellae is presently unknown. Previous studies on sponge zooxanthellae focused on morphology studied with electron microscopy (e.g. Vacelet 1981, Rützler 1990, Vicente 1990). The resulting observations were in good agreement with what is known from zooxanthellae found in other invertebrates, but revealed small differences in the ultrastructure (see Rützler 1990).
The present study investigates the genetic identity of Symbiodinium found in the common Great Barrier Reef (GBR) sponge Cliona orientalis Thiele, 1900 from 3 disparate locations situated in the path of the East Australian Current. The sponge has frequently been observed to attack live corals belonging to a wide range of taxa (Schönberg \& Wilkinson 2001). C. orientalis would thus have access to a large range of possible donors for its symbionts.

\section{MATERIAL AND METHODS}

Collection of samples. Tissue samples of the bioeroding sponge Cliona orientalis were obtained on SCUBA from disparate sites over a distance of more than $1300 \mathrm{~km}$ (Fig. 1): from Orpheus Island (Little Pioneer Bay) and the leeside of Pelorus Island $\left(18^{\circ} 40^{\prime} \mathrm{S}\right.$, $146^{\circ} 30^{\prime}$ E), Palm Island Group, Central Section GBR; from Heron Island and Wistari Reef $\left(23^{\circ} 26^{\prime} \mathrm{S}\right.$, $\left.151^{\circ} 55^{\prime} \mathrm{E}\right)$, Capricorn Bunker Group, Southern Section, GBR; and from Peel Island $\left(27^{\circ} 18^{\prime} \mathrm{S}, 153^{\circ} 06^{\prime} \mathrm{E}\right)$, Moreton Bay near Brisbane. Samples were taken between March 2003 and March 2004, from depths between 1 and $18 \mathrm{~m}$ (Table 1). Several paired samples of $C$. orientalis and invaded scleractinian corals were acquired. Samples were removed from the reef by using either hammer and chisel, or as cores with a hole saw attached to an air-driven drill.

Light microscopy. Sponges are known to host a multitude of symbionts, including a variety of phototrophic organisms (Vacelet 1981, Rützler 1990). Therefore, a subsample of sponge tissue fragments used for molecular analysis was initially checked for other zooxanthellate organisms that could pose as possible sources of contamination. Fragments of tissue were sampled from 10 different places of each of 11 sponge individuals, fixed in Biomeda Gel/Mount (aqueous mounting medium; Pro Sci Tech Australia) and assessed by light microscopy (Olympus BX41, at $\times 400$ ). All preparations included tissue from the surface and interior of the sponges (ectosome and endosome, respectively). Microscope slides were examined methodically by scanning back and forth across the samples.

DNA extraction. Small pieces of sponge-penetrated coral skeleton (about $5 \mathrm{~mm}^{3}$ ) were chopped with a razor blade to produce a coarse slurry. Occasional problems with amplification of symbiont DNA from the sponge were overcome by digesting whole, unhomogenized fragments, rather than working with slurries. This procedure improved the success rate by a factor of 5. Coral tissue was stripped from the skeleton by directed jets of high-pressure air. Samples were fixed in either $1 \mathrm{ml}$ of laboratory grade absolute ethanol or 


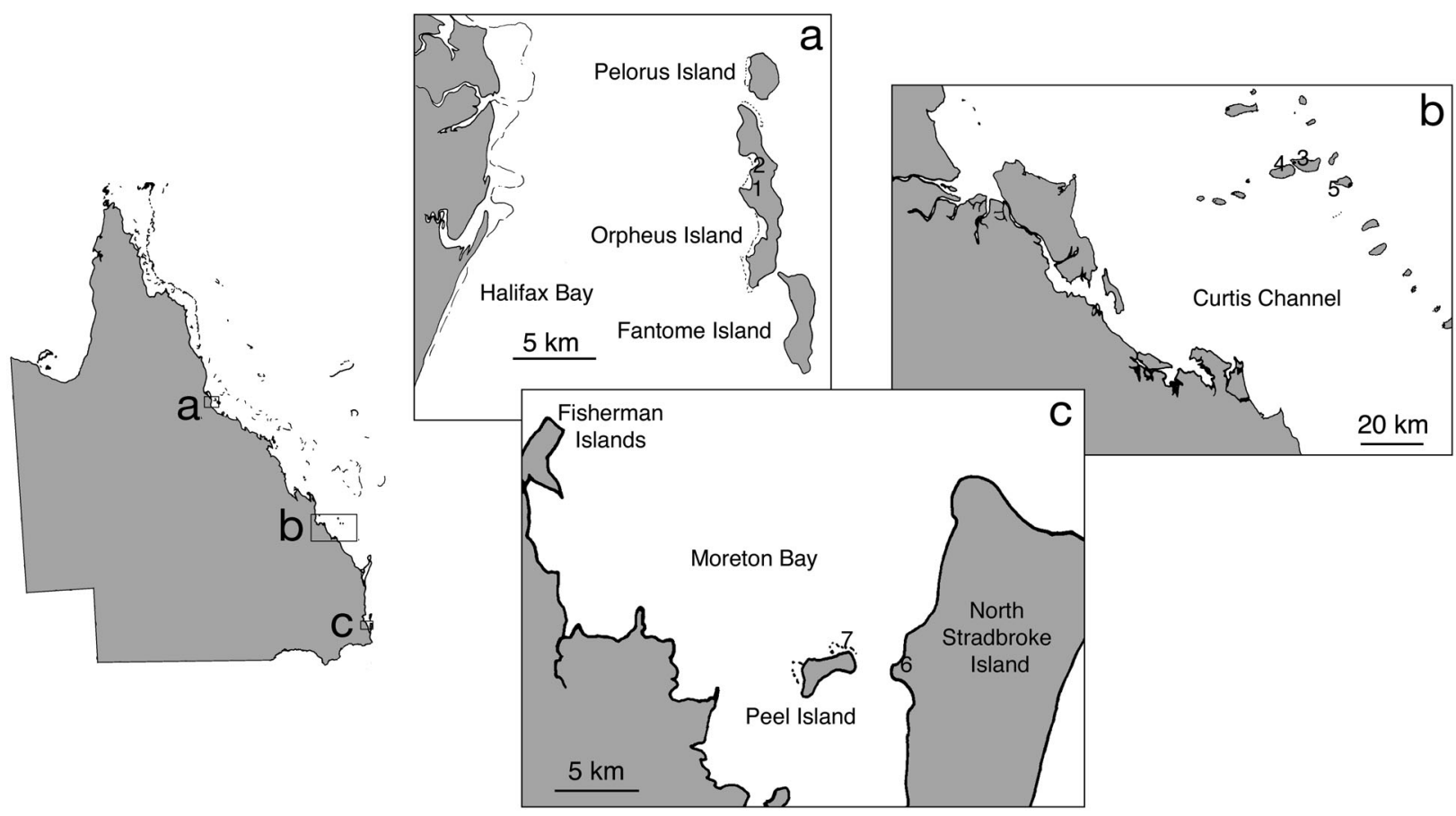

Fig. 1. Sample sites. (a) Part of the Palm Island Group. (1) Orpheus Island with Pioneer Bay and the Research Station and (2) Little Pioneer Bay, the main sample site. (b) Capricorn Bunker Group with (3) Heron Island and neighbouring research areas (4) Wistari Reef and (5) One Tree Island. (c) Peel Island with the Moreton Bay Research Station on (6) North Stradbroke Island and (7) the sample site east of the Lateral Marker

DNA preservative $(20 \%$ DMSO in 0.25 M EDTA, pH 8.0 and saturated with $\mathrm{NaCl}$ ).

DNA was extracted, amplified and visualized following the protocol given by Loh et al. (2001), including some modifications. Slurries and fragments in ethanol or DMSO were pelleted by centrifugation $(10000 \times \mathrm{g}$, $10 \mathrm{~min}, 21^{\circ} \mathrm{C}$ ). The pellet was washed twice by mixing with $500 \mu \mathrm{l}$ of DNAB buffer $(0.4 \mathrm{M} \mathrm{NaCl}, 50 \mathrm{mM}$ EDTA, $\mathrm{pH}$ 8.0; Rowan \& Powers 1991) and centrifuged as before. The pellets were resuspended for a third time in DNAB and incubated in $1 \%$ sodium dodecyl-sulfate (Boehringer Mannheim) for $1 \mathrm{~h}$ at $65^{\circ} \mathrm{C}$. The digestion was carried out with proteinase K (Boehringer Mannheim) in a final concentration of $0.5 \mathrm{mg} \mathrm{ml}^{-1}$. After incubation at $37^{\circ} \mathrm{C}$ for 8 to $12 \mathrm{~h}$, an equal volume of phenol was added to the digestion product, which was mixed and centrifuged $\left(10000 \times \mathrm{g}, 10 \mathrm{~min}, 21^{\circ} \mathrm{C}\right)$. The aqueous phase was subjected to a second extraction, using phenol-chloroform $(25: 24)$ and a third extraction using chloroform-isoamyl alcohol (25:1). DNA was precipitated by adding one-tenth volume of $3 \mathrm{M}$ sodium acetate $(\mathrm{pH} 5.2)$ and an equal volume of cold isopropanol $\left(0^{\circ} \mathrm{C}\right)$, followed by centrifugation. The precipitate was washed with $70 \%$ ethanol, dried, dissolved in $50 \mu \mathrm{l}$ of sterile TE buffer, and stored at $-10^{\circ} \mathrm{C}$.

PCR amplification. The variable domains D1 and D2 of the 28S rRNA gene of the symbiotic dinoflagellates were PCR-amplified using a primer set as in Loh et al. (2001). The domains were forward 5'-CCC GCT GAA TTT AAG CAT ATA AGT AAG CGG-3' and reverse 5'-GTT AGA CTC CTT GGT CCG TGT TTC AAG A$3^{\prime}$ (position 26 and 741 respectively in the $28 \mathrm{~S}$ rDNA sequence of the free-living dinoflagellate, Prorocentrum micans, GenBank accession no. X16108).

The DNA content of each sample was evaluated spectrophotometrically in a 1:100 dilution in distilled water in a quartz cuvette. PCR reactions were prepared with $0.4 \mu \mathrm{g}$ of template DNA, $5 \mu \mathrm{l}$ of $10 \times$ PCR buffer (1 M Tris-HCl $[\mathrm{pH} 8.3], 0.5 \mathrm{M} \mathrm{KCl}, 15 \mathrm{mM}$ $\left.\mathrm{MgCl}_{2}\right), 1 \mu \mathrm{l}$ of $10 \mathrm{mM}$ total dNTP, $20 \mathrm{pmol}$ of each primer and 5 units of Taq polymerase (Ampli-Taq, Perkin Elmer) and $40 \mu \mathrm{g}$ DNAase-free bovine serum albumin (BSA, Pharmacia) in a total volume of $50 \mu \mathrm{l}$. BSA was used to relieve the inhibition of PCR reactions by natural substances that may be present with DNA extracted from wild-type environments. Its use and efficacy is summarised by Kreader (1996). Amplifications were conducted in a PCR Express thermal cycler (Hybaid Ltd) with the following parameters: $95^{\circ} \mathrm{C}$ for $1 \mathrm{~min}, 65^{\circ} \mathrm{C}$ for $2 \mathrm{~min}$, and $72^{\circ} \mathrm{C}$ for $3 \mathrm{~min}$ ( 35 cycles). The PCR products were analysed by electrophoresis in $2 \%$ agarose gels $\left(10 \mathrm{~V} \mathrm{~cm}^{-1} ; 40 \mathrm{~mA}\right)$. After staining with ethidium bromide, they were visualized with UV transillumination. 
Table 1. Cliona orientalis sample information with respective coral samples, and GenBank accession numbers for available sequenced material. C: coral; CG: Coral Gardens; HB: Harry's Bommie; HI: Heron Island; LPB; Little Pioneer Bay; OI: Orpheus Island; PI: Peel Island; east of Lateral Marker; PL: back of Pelorus Island; S: sponge; WIS: Wistari Lagoon. All samples presented here were in the encrusting growth form, except for OI-S17, which was in the younger, papillate growth form

\begin{tabular}{|c|c|c|c|c|c|c|c|}
\hline $\begin{array}{l}\text { Sponge } \\
\text { sample no. }\end{array}$ & $\begin{array}{l}\text { Sponge GenBank } \\
\text { accession no. }\end{array}$ & Substrate & $\begin{array}{c}\text { Coral } \\
\text { sample no. }\end{array}$ & $\begin{array}{c}\text { Coral GenBank } \\
\text { accession no. }\end{array}$ & $\begin{array}{l}\text { Sample } \\
\text { location }\end{array}$ & $\begin{array}{l}\text { Sample } \\
\text { depth (m) }\end{array}$ & $\begin{array}{l}\text { Sample } \\
\text { date }\end{array}$ \\
\hline OI-S01 & - & Massive Porites sp. & OI-C01 & - & LPB & 2.0 & 11 Mar 2003 \\
\hline OI-S05 & AY725458 & Massive Porites sp. & OI-C05 & - & LPB & 2.0 & 11 Mar 2003 \\
\hline OI-S06 & AY725459 & Faviid coral & OIC06 & - & PL & 1.5 & 09 Mar 2003 \\
\hline OI-S07 & AY725460 & Next to Xestospongia cf. exigua & - & - & LPB & 1.0 & 11 Mar 2003 \\
\hline OI-S08 & - & Massive Porites sp. & OI-C08 & - & LPB & 2.0 & 11 Mar 2003 \\
\hline OI-S09 & AY738461 & Massive Porites sp. & OI-C09 & - & LPB & 2.0 & 11 Mar 2003 \\
\hline OI-S10 & - & Massive Porites sp. & OI-C10 & - & LPB & 2.5 & 11 Mar 2003 \\
\hline OI-S17 & - & In bivalve shell & - & - & LPB & 2.0 & 12 Mar 2003 \\
\hline OI-S26 & AY725461 & Massive Porites sp. & OI-C26 & - & LPB & 0.8 & 25 Oct 2003 \\
\hline OI-S42 & AY725462 & Encrusting Montipora sp. & OI-C42 & AY780881 & $\mathrm{LPB}$ & 2.8 & 27 Oct 2003 \\
\hline HI-S01 & AY725457 & Dead Acropora sp. & - & - & WIS & 4.0 & 15 May 2003 \\
\hline HI-S02 & AY780874 & Massive Porites sp. & HI-C02 & - & $\mathrm{CG}$ & 16.0 & 12 Jan 2004 \\
\hline HI-S03 & AY780875 & Massive Porites sp. & HI-C03 & - & $\mathrm{CG}$ & 18.0 & 12 Jan 2004 \\
\hline HI-S05 & AY780876 & Massive Porites sp. & HI-C05 & - & $\mathrm{CG}$ & 12.0 & 12 Jan 2004 \\
\hline HI-S16 & - & Massive Porites sp. & $\mathrm{HI}-\mathrm{C} 16$ & - & $\mathrm{HB}$ & 13.5 & 01 Aug 2003 \\
\hline HI-S19 & - & Massive Porites sp. & HI-C19 & - & $\mathrm{HB}$ & 14.0 & 01 Aug 2003 \\
\hline MB-S01 & AY780877 & Faviid coral & MB-C01 & - & PI & 2.0 & 15 Dec 2003 \\
\hline MB-S02 & AY780878 & Faviid coral & $\mathrm{MB}-\mathrm{C} 02$ & AY780882 & PI & 1.8 & 15 Dec 2003 \\
\hline MB-S04 & AY780879 & Dead block & - & - & PI & 2.0 & 15 Dec 2003 \\
\hline MB-S05 & AY780880 & Dead block & - & - & PI & 1.9 & 15 Dec 2003 \\
\hline MB-S06 & AY738460 & Faviid coral & MB-C06 & - & PI & 2.0 & 15 Dec 2003 \\
\hline MB-S12 & & Dead block & - & - & PI & 1.0 & 17 Mar 2004 \\
\hline MB-S13 & & Dead block & - & - & PI & 0.8 & 17 Mar 2004 \\
\hline
\end{tabular}

Single stranded conformational polymorphism. We employed single stranded conformational polymorphism (SSCP) to assess the similarity or dissimilarity of the samples (Schwieger \& Tebbe 1998). The method is capable of differentiating gene sequences that differ by as few as 1 base (Sheffield et al. 1993). The technique relies on the initial denaturation of DNA into single strands that fold onto themselves. These folded structures will differ in conformation depending on base sequence and run at different electrophoretic mobility in a polyacrylamide gel to produce distinct patterns that reflect the diversity of genes present (Orita et al. 1989). Additionally, the number of symbiont rDNA genotypes amplified from a coral may be indicated by the number of single stranded bands produced in the SSCP gel (1 genotype $=2$ bands of single stranded DNA).

For SSCP analyses, 20 to $40 \mu \mathrm{l}$ of the PCR product were mixed with an equal volume of loading buffer (95\% formamide, $10 \mathrm{mM} \mathrm{NaOH}, 0.25 \%$ bromophenol blue and $0.25 \%$ xylene cyanol) and denatured for $5 \mathrm{~min}$ at $95^{\circ} \mathrm{C}$. After denaturing the mixed aliquots were immediately chilled on crushed ice and run in a 37.5:1 acrylamide: bis-acrylamide gel (Amresco) in $0.6 \times \mathrm{TBE}$ at $160 \mathrm{~V}$ for $14 \mathrm{~h}$ at room temperature. The SSCP patterns were stained with ethidium bromide and visualized with UV transillumination.
DNA sequencing. PCR amplifications were purified for direct sequencing using the JETquick PCR purification spin kit (GENOMed $\mathrm{GmbH}$ ). The sequence was determined from both ends of the purified PCR product using BigDye Terminator Versions 3.1 and the ABI 3730xl automated sequencer (both Applied Biosystems). Sequencing took place at the Australian Genome Research Facility of the University of Queensland, Australia.

Phylogenetic analyses. We conducted a BLAST search in GenBank with our derived sequences as search queries. The closest matches were used as reference sequences for subsequent alignments and analyses. Sequences were aligned using CLUSTAL W (Thompson et al. 1994). Gymnodinium beii was chosen as an outgroup (accession no. AF060900; Wilcox 1998). Trees were constructed using the neighbour-joining (NJ), maximum likelihood (ML), maximum parsimony (MP) and Bayesian methods. ML and MP analyses were conducted using the PAUP beta version $4.0 \mathrm{~b} 10$ (Swofford 2002). NJ was conducted using the PHYLIP package version 3.5c (Felsenstein 1993).

The NJ algorithm was implemented with Kimura 2parameter distances and assessed with 1000 bootstrap replicates. For ML, the program MODELTEST version 2.06 (Posada \& Crandall 1998) was used to determine 
the most appropriate substitution model for the data. These were TrNef + G using the hierarchical likelihood ratio test (hLRT) and $(\operatorname{TrN}+\mathrm{I}+\mathrm{G})$ selected by the Akaike Information Criterion (AIC). ML trees were assessed with 100 bootstraps. The MP analysis was carried out by the heuristic search method, and starting-trees were obtained by stepwise-addition using simple addition sequence. A single tree was held at each step. The criteria for tree-swapping used a treebisection-reconnection algorithm. MP trees were assessed with 100 bootstrap replicates. The Bayesian tree reconstruction was implemented in the 'MrBayes' program by Ronquist \& Huelsenbeck (2003). Two analyses based on the TrNef $+\mathrm{G}$ and TrNef $+\mathrm{I}+\mathrm{G}$ models selected above were undertaken. Starting from random trees, 4 Markov chains were run in parallel to sample trees using the Markov Chain Monte Carlo (MCMC) principle. After the burn-in phase every 100th sample out of $10^{6}$ generations was considered, and results were compared among the 4 chains in order to confirm that stationality has been reached. The phylogenetic trees generated were visualized using TREEVIEW version 1.6.5 (Page 1996).

Comparison of populations. With 4 to 6 sequences per sample region, we tested whether the sponge Symbiodinium populations were genetically connected or isolated. Pairwise distances of symbiont populations from host sponges between their regions were calculated with Kimura's 2-parameter model using the program Arlequin version 2.000 (Schneider et al. 2000).

\section{RESULTS}

\section{Light microscopic examination of sponge symbionts}

Microscopic inspection of subsamples of sponge ectosome and endosome confirmed that Cliona orientalis contained very dense populations of intracellular dinoflagellates (Fig. 2a). About $90 \%$ of the symbionts were concentrated in the uppermost millimetre of the sponges. Cell densities rapidly decreased with distance into the sponges and were then evenly distributed. No phototrophic organisms other than Symbiodinium were observed in the endosome of the sponges. Two foraminiferans were found adhering to the spicular palisade of the surface of 2 samples (Fig. 2b,c). The foraminiferans were identified as the buliminid Bolovina cf. pseudoplicata and the miliolid Qunqueloculina cf. villafranca, both general forms with wide distributions (K. Nielsen, pers. comm.). Neither of the foraminiferans was known to contain zooxanthellae. The lack of other zooxanthellate organisms in the tissues of $C$. orientalis showed that the dominant source of amplified zooxanthellar DNA was the sponge itself.

\section{PCR and SSCP}

Symbiodinium partial 28S ribosomal DNA was amplified from over 40 samples of Cliona orientalis originating from Pelorus, Orpheus, Heron and Peel Islands and Wistari Reef. The size of the PCR product from symbionts found in the sponge was approximately 650 bases. The derived SSCP banding patterns were very uniform and each consisted of 2 widely separated bands (= 2 single-stranded DNA fragments; Fig. 3). This pattern indicated that each sponge contained Symbiodinium populations of predominantly 1 phylotype. This was observed throughout the entire sample series, with the possible exceptions of samples OI-S05 and OI-S06 in the second acrylamide gel and
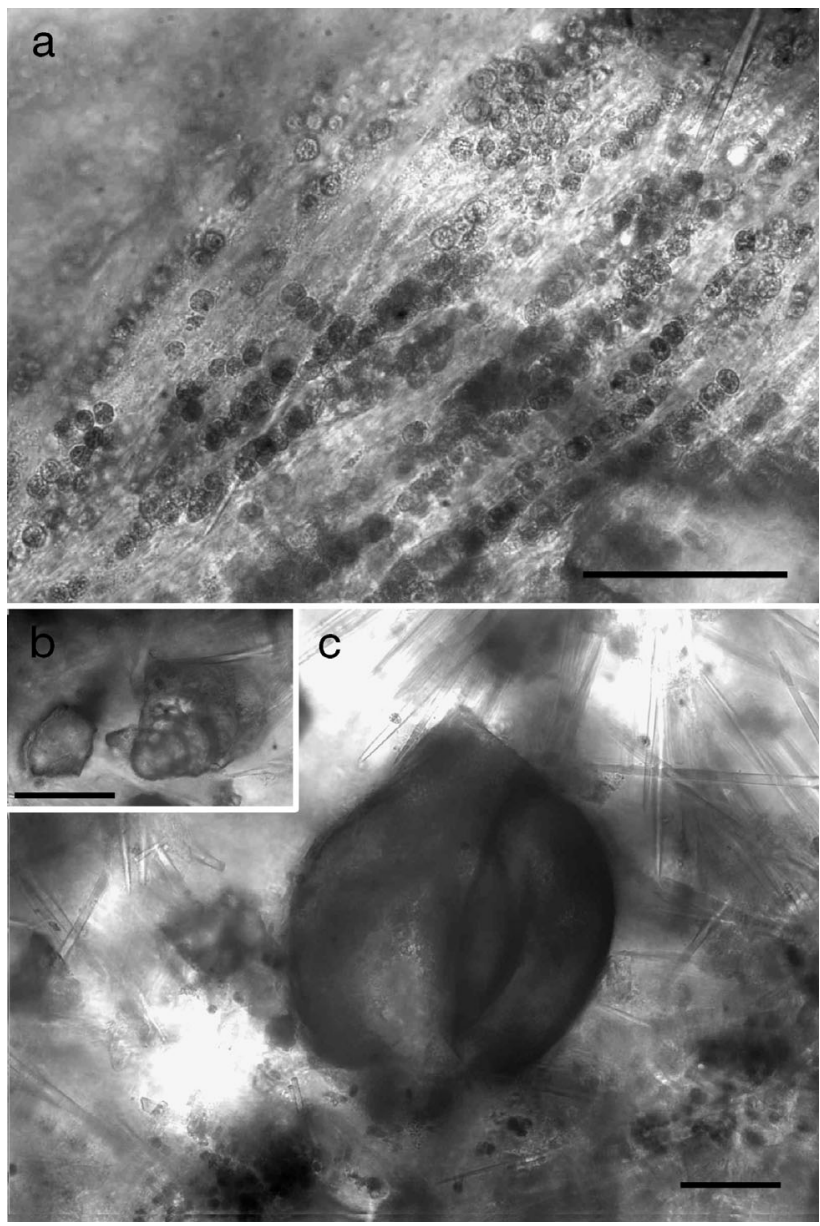

Fig. 2. Cliona orientalis. Tissue preparations for light microscopy. (a) C. orientalis endosome with a dense community of Symbiodinium. (b) Bolivina cf. pseudoplicata (buliminid foramiferan). (c) Qunqueloculina cf. villafranca (milioid foraminiferan). Scale bars all $100 \mu \mathrm{m}$. Both foraminiferans were found caught in the spicular palisade, i.e. in spicule brushes projecting from the sponge surface. Objects near scale bars in (a) and (b) are sponge chips 
OI-S17 and HI-S01 of the third acrylamide gel in Fig. 3 (origin of samples listed in Table 1). The 4 samples each had 2 extra bands. However, the samples OI-S05 and OI-S06 of the second gel (with extra bands) are identical to OI-S05 and OI-S06 of the third gel (no extra bands) and were run from the same PCR products. We therefore assumed that occasional extra bands originated from alternative possibilities in folding patterns of denatured single DNA strands and that they are unlikely to represent contamination or multiple phylotypes. None of the SSCP patterns showed correlation to spatial and temporal variation of the samples' origins: i.e. different locations, depths, seasons, growth forms of the sponges and neighbouring organisms did not generate different SSCP patterns (Table 1, Fig. 3). The similarity of the patterns indicated that Symbiodinium populations from Pelorus, Orpheus, Heron and Peel Islands and Wistari Reef were comprised of an identical phylotype or closely related phylotypes.

Coral Symbiodinium SSCP banding patterns differed completely from that of corresponding sponges in paired samples (Fig. 3). This indicated that clades and phylotypes of Symbiodinium from corals were different to those of the respective invading bioeroding sponges.

\section{DNA sequencing and phylogenic analysis and differences among sponge Symbiodnium populations}

A total of 15 unambiguous DNA sequences of the PCR products were obtained from sponge symbionts off Pelorus, Orpheus, Heron, and Peel Islands and Wistari Reef (Table 1). The sequences were deposited in GenBank (see Table 1 for accession numbers). BLAST searches revealed that the most closely related Symbiodinium phylotypes were derived from soritid foraminiferans (clade G) (Fig. 4). However, the maximum sequence identity of Symbiodinium phylotypes from $C$. orientalis and foraminiferans was only $93 \%$ and therefore distinct from the foraminiferal symbionts. Our data suggest that $C$. orientalis contains symbionts that may constitute a new subclade of G. Sequence identities between sponge symbionts were higher than compared to foraminiferan symbionts, with $99.0 \%$ between samples from the Capricorn Bunker Group and Moreton Bay, 99.4\% between the Palm Islands and Moreton Bay, and $99.7 \%$ between the Capricorn Bunker Group and the Palm Islands. The other known Symbiodinium clades A, B, C, D and F were included in further analyses. Clade $\mathrm{E}$ and $\mathrm{H}$ 28S ribosomal DNA were not available at the time of this study and were therefore excluded from our analyses.

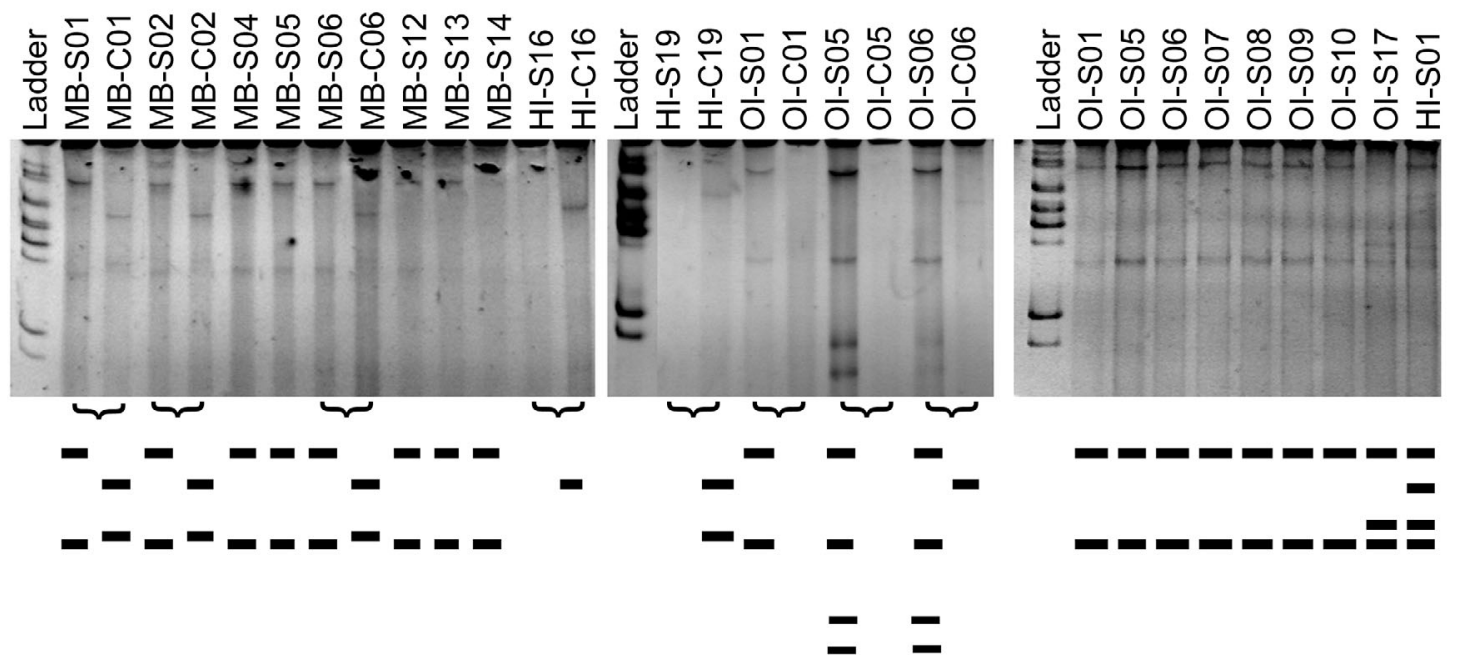

Fig. 3. Symbiodinium sp. banding patterns of single strand 28S ribosomal DNA in acrylamide gels. Profiles were gained from the sponge Cliona orientalis (S) and from various corals (C). Sample pairs of $C$. orientalis and the respective invaded coral are marked by a bracket $(\sim \sim$ ). Profiles from sponge symbionts clearly differed from profiles from coral symbionts. However, within all sponge samples profiles were very consistent between samples taken from different environments (HI: Heron Island, MB: Moreton Bay, OI: Orpheus Island) and growth forms (the second last sample 'OI-S17' was papillate, whereas all others were encrusting). As bands are partly weak, a diagrammatic representation of recognisable bands was included underneath the photographs of the gels. Extra bands in 'OI-S05' and 'OI-S06' in the second gel are considered to be artefacts, as both samples did not show these structures in the third gel. Extra bands in 'OI-S17' and 'HI-S01' in the third gel are also likely to be artefacts. Further possibilities include multiple symbionts or contamination, but the latter was considered unlikely 
The trees constructed by using NJ, ML, MP and Bayesian algorithms were congruent in topology. Only the ML tree is shown with the results of bootstrap analyses from all analyses (Fig. 4). All samples of sponge Symbiodinium clustered together in a wellsupported sister group to the well-supported clade G. Weakly supported subgroups of the 3 sample regions were also observed in the sponge cluster, with a slight overlap between the Palm Islands and the Capricorn Bunker Group (Pelorus and Wistari samples, Fig. 4). The BLAST search and the tree topology clearly demonstrated that the sponge symbionts are not in the recognised Symbiodinium clade categories of A, B, C, D or F. The sponge symbionts are closest to clade $G$ and possibly a new subclade of $\mathrm{G}$.

The Symbiodinium phylotypes of 2 corals (OI-C42 and MB-C02) infected by Cliona orientalis (OI-S42 and MB-S02 respectively) clustered in clade C. This confirmed that the symbiont populations of host corals infected by $C$. orientalis were distinct.

Despite the observed high sequence identities between the sampling regions Palm Islands, Capricorn Bunker Group and Moreton Bay, symbiont populations appeared to be genetically isolated. This was shown by Kimura's 2-parameter model, involving pairwise comparisons with $\Phi S T$ test statistics. Small subsamples of the populations of all the 3 locations differed significantly from each other, with the strongest support between the Orpheus Island versus the Moreton Bay population ( $\mathrm{p}$ for $\mathrm{OI}$ vs. $\mathrm{MB}=0.002$, OI vs. $\mathrm{HI}=0.018$, HI vs. $M B=0.014)$. The $\Phi S T$ values between these populations ranged from 0.62 to 0.70 .
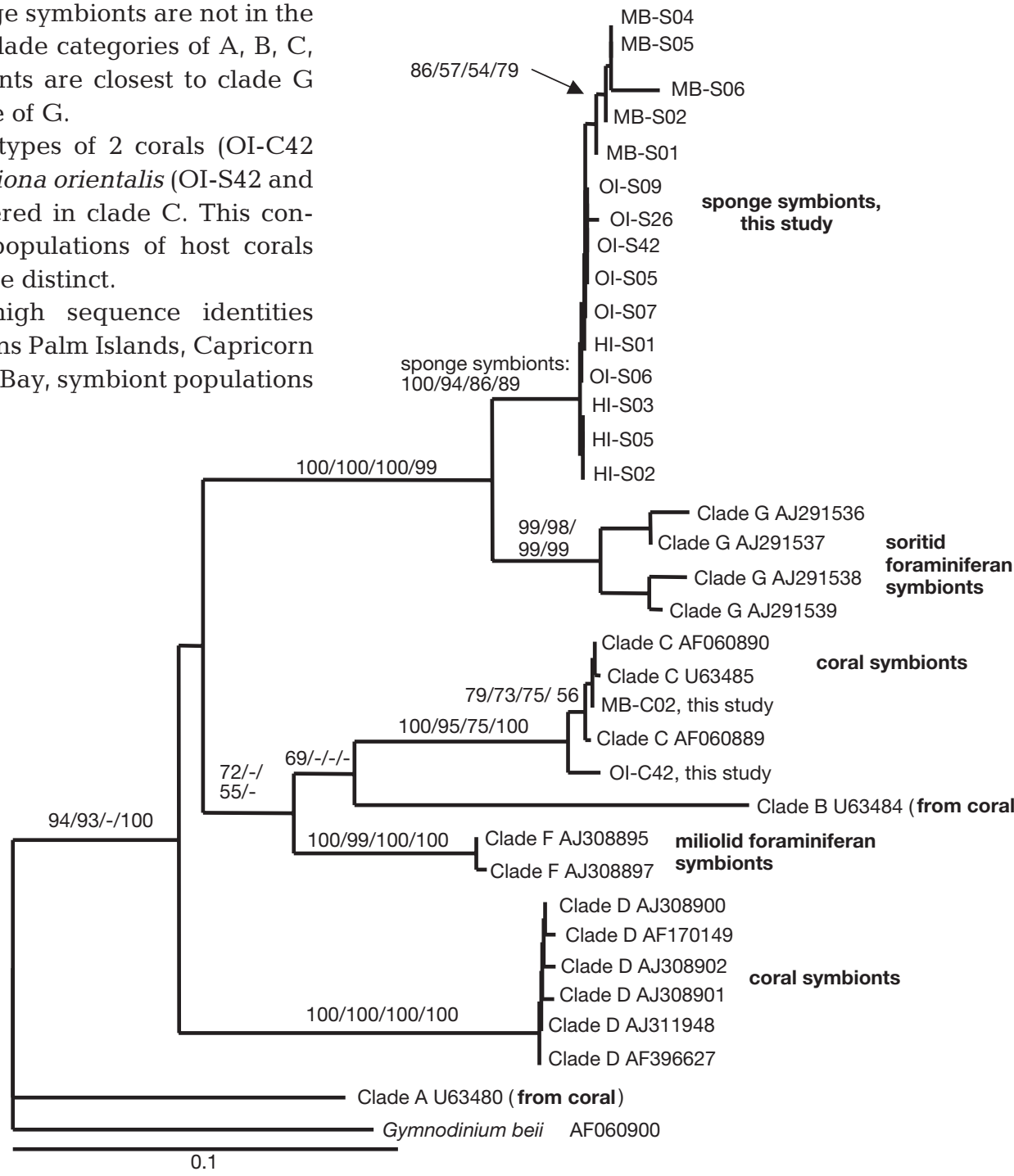

Fig. 4. Symbiodinium sp. from the bioeroding sponge Cliona orientalis in comparison with known clades of Symbiodinium. Maximum likelihood tree derived from the D1/D2 domains of the 28S ribosomal gene. Symbionts from our study are marked with prefixes OI-, HI- and MB- for the sample areas Palm Islands, Capricorn Bunker Group and Moreton Bay, respectively. Distances are number of substitutions per 100 bases. Unless otherwise indicated, only bootstrap values greater than $50 \%$ are shown at the nodes (neighbour joining/maximum likelihood/maximum parsimony/Bayesian). The outgroup-sequence was from the free-living dinoflagellate, Gymnodinium beii (Wilcox 1998). Remaining clades included were coral symbiont clades A, B and C standards (accession nos. U63480, U63484 and U63485, respectively; Baker et al. 1997); clade D standard (accession no. AF170149; Baker 2003); clade C (AF060889 and AF060890; Wilcox 1998); clade G miliolid foraminiferan symbionts (accession nos. AJ291536-9 respectively; Pawlowski et al. 2001); soritid foraminiferan symbionts (AJ308895 and AJ308897, Pochon et al. 2001). GenBank accession numbers are displayed for sequences from other studies. For our samples, accession numbers are listed in Table 1 


\section{DISCUSSION}

\section{The sponge-dinoflagellate symbiosis}

The molecular diversity and biogeography of Symbiodinium from Cliona orientalis along the path of the East Australian Current did not differ as strongly as for other organisms. Previous studies of corals and anemones demonstrated that their Symbiodinium clades varied with latitudinal distribution of the hosts (Loh et al. 2001, Rodriguez-Lanetty et al. 2001). This contrasts with our results, which demonstrate that symbiont populations from sponge individuals located 600 to $1300 \mathrm{~km}$ apart show only low levels of diversity.

\section{Symbiont origin}

The symbiont phylotypes of Cliona orientalis in this study formed a group distinct to all Symbiodinium clades deposited in GenBank and those associated with the specific coral colonies that the sponge invaded. Although comparable 28S rDNA sequences for clade $\mathrm{E}$ and $\mathrm{H}$ were unavailable for comparison during the study, it is unlikely that the sponge symbionts belong to either clade, because a previous $18 \mathrm{~S}$ rRNA gene analysis (Baker 2003) showed that clade $\mathrm{E}$ dinoflagellates are only distantly related to clade $\mathrm{G}$, the sister group of our samples. Moreover, clade E appears to be represented by a free-living dinoflagellate, Gymnodinium varians (Wilcox 1998). According to recent phylogenetic results using 28S rDNA sequence data, clade $\mathrm{H}$ groups together with clade $\mathrm{C}$, but is different from G (Pochon et al. 2004).

The evidence implies that the sponge symbionts possibly represent a new subclade of G-type Symbiodinium. It suggests that the symbiosis between bioeroding sponges and Symbiodinium has developed independently from the corals they invade. Therefore, this study did not support the hypothesis that Cliona orientalis can obtain symbiotic dinoflagellates from corals. Vertical transmission of Symbiodinium has been observed for $C$. viridis (Mariani et al. 2000, 2001), and very likely also occurs in $C$. orientalis. This strategy enables continuity and faithful transmission of the same symbiont phylotype from generation to generation, which results in very close and stable relationships between a host and its symbionts (Douglas 1998). This would explain the consistency of our results for $C$. orientalis symbionts and their distinction from symbionts of other groups.

Symbioses with clade G Symbiodinium appear to have developed later than most zooxanthellate symbioses known from corals as the phylogenetic position of clade $\mathrm{G}$ is more derived than for clades A to F. We can only speculate which organisms acquired G-type symbionts first and whether they were taken up several times independently or whether at some stage they were transmitted from one organism group to the next (e.g. Lee et al. 1995). It is equally possible that Cliona orientalis may have taken up symbionts from foraminiferans, or that foraminiferans received symbionts from sponges, or that either group received their symbionts from other independent sources. The most likely mode of initial uptake, however, appears to be by feeding on dinoflagellates or on organisms that contain dinoflagellates (Rosell 1993, Lee et al. 1995).

\section{Symbiont geographic diversity}

Subsamples of the Symbiodinium populations were genetically isolated between the 3 sample regions Palm Islands, Capricorn Bunker Group and Moreton Bay. However, only between 4 and 6 samples per site were available, hence this result will have to be confirmed by more detailed studies. Assuming vertical transmission of sponge symbionts as a rule, we have to accept that Symbiodinium distribution patterns are governed by sponge dispersal abilities. Larvae of bioeroding sponges do not have an extended swimming phase and move around by creeping (Warburton 1966, Mariani et al. 2000, 2001), thus their dispersal by currents is limited. Moreover, the latitudinal differences may select for phylotypes better adapted to respective environments. Moreton Bay is part of a marine region that borders the temperate zone of the Australian East Coast and has been identified as a marginal environment distinguished by a combination of endemic tropical and temperate species (Davie \& Hooper 1998). The Palm Islands and Heron Island are subject to different levels of temperature stress. Both regions have experienced severe bleaching events due to elevated temperatures (Berkelmans \& Willis 1999), but Heron Island has additionally been exposed to situations of extremely low temperatures, again resulting in bleaching events (Hoegh-Guldberg et al. 2005). We would expect that a broadscale survey of symbiont populations of this bioeroding sponge would reveal different phylotypes depending on how genetically connected or isolated they are. The same was shown for Symbiodinium populations of the widely distributed and maternally transmitting coral, Seriatopora hystrix (Loh et al. 2001).

\section{Physiological and ecological implications}

Physiological responses to environmental stressors differ between corals and bioeroding sponges. Bioeroding sponges have been observed to be more 
bleaching-resistant than corals (Vicente 1990, Schönberg \& Wilkinson 2001). Bleaching phenomena stem from environmental factors that adversely affect the photosynthetic processes of Symbiodinium (HoeghGuldberg 1999). As Cliona orientalis contains different dinoflagellate clades and phylotypes than its sympatric corals, this may explain part of the contrasting behaviour. Coral symbionts have recently been tested for differences in their physiology. Corals with clade D Symbiodinium were better adapted to thermal stress than corals with other clades (Baker et al. 2004, Fabricius et al. 2004, Rowan 2004), and by implication, more resistant to bleaching.

Cliona orientalis may alternatively offer a more sheltered environment to its symbionts than corals, given that the sponge tissue penetrates hard substrates to an average depth of $1.3 \mathrm{~cm}$, and that symbionts can be redistributed according to environmental conditions (Schönberg 2000). We originally considered, whether sponge tissue may act as a refuge for vulnerable coral zooxanthellae. However, by rejecting the hypothesis that $C$. orientalis may take up symbionts from invertebrates it invades under normal conditions, we also abandoned the convenient concept of fostersymbionts. Further studies that investigate the physiology and photosynthesis of $C$. orientalis and their symbionts are underway and may indicate whether the unique Symbiodinium phylotype found by us expresses phenotypes that enable the sponge to resist environmental stress.

Acknowledgements. We would like to thank staff at the research stations at Orpheus, Heron and Stradbroke Islands for their competent assistance. We would also like to acknowledge help in the field from H. Cambourn, E. Cebrian, G. Holmes and R. Olbrich. Colleagues at the Centre for Marine Studies at The University of Queensland, St. Lucia, Australia occasionally assisted in the laboratory and tried various extraction methods with us: P. Fisher, M. Gomez, A. Lau, W. Leggat and E. Sampayo. K. Nielsen from the University of Copenhagen, Denmark identified foraminiferans found on the sponge surfaces. We appreciate comments on the manuscript prior to submission from P. Fisher, F. McIntosh and J. Roff. C.S. is supported by a Feodor-Lynen-Fellowship from the Alexander von Humboldt Foundation, Bonn, Germany.

\section{LITERATURE CITED}

Baker A (2003) Flexibility and specificity in coral-algal symbiosis: diversity, ecology, and biogeography of Symbiodinium. Ann Rev Ecol Evol Syst 34:661-689

Baker A, Rowan R, Knowlton N (1997) Symbiosis ecology of 2 Caribbean acroporid corals. Proc 8th Int Coral Reef Symp, Panama 2:1295-1300

Baker AC, Starger CJ, McClanahan TR, Glynn W (2004) Corals' adaptive response to climate change. Shifting to new algal symbionts may safeguard devastated reefs from extinction. Nature 741:430
Berkelmans R, Willis BL (1999) Seasonal and local spatial patterns in the upper thermal limits of corals on the inshore central Great Barrier Reef. Coral Reefs 18:219-228

Davie PJF, Hooper JNA (1998) Patterns of biodiversity in marine invertebrate and fish communities of Moreton Bay. In: Tibbetts IR, Hall NJ, Dennison WC (eds) Moreton Bay and Catchment. University of Queensland, St. Lucia, p 331-346

Davies PS (1992) Endosymbiosis in marine cnidarians. In: John DM, Hawkins SJ, Prince JH (eds) Plant-animal interactions in the marine benthos. Special volume 46. The Systematics Association. Clarendon Press, Oxford, p 511-540

Douglas A (1998) Host benefit and the evolution of specialization in symbiosis. Heredity 81:599-603

Fabricius KE, Mieog JC, Colin PL, Idip D, van Oppen MJH (2004) Identity and diversity of coral endosymbionts (zooxanthellae) from 3 Palauan reefs with contrasting bleaching, temperature and shading histories. Molecular Ecol 13: 2445-2458

Felsenstein, J (1993) PHYLIP (Phylogeny Inference Package) version 3.5c. Seattle Department of Genetics, University of Washington, Seattle, WA

Freudenthal HG (1962) Symbiodinium gen. nov. and Symbiodinium microadriaticum sp. nov., a zooxanthella: taxonomy, life cycle, and morphology. J Protozool 9:45-52

Garson MJ, Clark RJ, Webb RI, Field KL, Charan RD, McCaffrey EJ (1999) Ecological role of cytotoxic alkaloids: Haliclona n. sp., an unusual sponge/dinoflagellate association. Mem Queensland Mus 44:205-213

Hill MS (1999) Morphological and genetic examination of phenotypic variability in the tropical sponge Anthosigmella varians. Mem Queensland Mus 44:239-247

Hill MS, Wilcox TP (1998) Unusual mode of symbiont repopulation after bleaching of Anthosigmella varians: acquisition of different zooxanthellae strains. Symbiosis 25: $279-289$

Hoegh-Guldberg O (1999) Climate change, coral bleaching and the future of the world's coral reefs. Mar Freshw Res 50:839-866

Hoegh-Guldberg O, Fine M, Skirving W, Johnstone R, Dove S, Strong A (2005 Coral bleaching following wintry weather. Limnol Oceanogr 50(1):265-271

Kawaguti S (1944) On the physiology of reef corals. VII. Zooxanthella of the reef corals is Gymnodinium sp., Dinoflagellata; its culture in vitro. Palao Trop Biol Stat Stud 2(4):675-679

Kreader CA (1996) Relief of amplification inhibition in PCR with bovine serum albumin or T4 gene 32 protein. Appl Environ Microbiol 62:1102-1106

LaJeunesse TC, Loh WKW, van Woesik R, Hoegh-Guldberg O, Schmidt GW, Fitt WK (2003) Low symbiont diversity in southern Great Barrier Reef corals, relative to those of the Caribbean. Limnol Oceanogr 48:2046-2054

Lee JJ, Wray CG, Lawrence C (1995) Could foraminiferal zooxanthellae be derived from environmental pools contributed to by different coelenterate hosts? Acta Protozool 34:75-85

Loh W, Loi T, Carter D, Hoegh-Guldberg O (2001) Genetic variability of the symbiotic dinoflagellates from the wide ranging coral species, Seriatopora hystrix and Acropora longicyathus, in the Indo-West Pacific. Mar Ecol Prog Ser 222:97-107

Mariani S, Piscitelli MP, Uriz MJ (2001) Temporal and spatial co-occurrence in spawning and larval release of Cliona viridis (Porifera : Hadromerida). J Mar Biol Assoc UK 81: 565-567 
Mariani S, Uriz MJ, Turon X (2000) Larval bloom of the oviparous sponge Cliona viridis: coupling of larval abundance and adult distribution. Mar Biol 137:783-790

Orita, M, Iwahana H, Kanazawa H, Hayashi K, Sekiya T (1989) Detection of polymorphism of human DNA by gel electrophoresis as single-strand conformation polymorphisms. Proc Natl Acad Sci USA 86:2766-2770

Page RDM (1996) TREEVIEW: An application to display phylogenetic trees on personal computers. Computer Applications Biosci 12:357-358

Pawlowski J, Holzmann M, Fahrni JF, Pochon X, Lee JJ (2001) Molecular identification of algal endosymbionts in large miliolid. J Eukaryot Microbiol 48:368-373

Pochon X, LaJeunesse T, Pawlwoski J (2004) Biogeographic partitioning and host specialization among foraminiferan dinoflagellate symbionts (Symbiodinium, Dinophyta). Mar Biol 146:17-27

Pochon XC, Pawlowski J, Zaninetti L, Rowan RG (2001) High genetic diversity and relative specificity among Symbiodinium-like endosymbiotic dinoflagellates in soritid foraminiferans. Mar Biol 139:1069-1078

Posada D, Crandall KA (1998). Modeltest: testing the model of DNA substitution. Bioinformatics 14:817-818

Rodriguez-Lanetty M, Loh W, Carter D, Hoegh-Guldberg O (2001) Latitudinal variability in symbiont specificity within the widespread coral Plesiastrea versipora. Mar Biol 138: $1175-1181$

Ronquist F, Huelsenbeck JP (2003) MrBayes 3: Bayesian phylogenetic inference under mixed models. Bioinformatics 19:1572-1574

Rose CS, Risk MJ (1985) Increase in Cliona delitrix infestation of Montastrea cavernosa heads on an organically polluted portion of the Grand Cayman fringing reef. Mar Ecol 6: 345-363

Rosell D (1993) Effects of reproduction in Cliona viridis (Hadromerida) on zooxanthellae. Sci Mar 57:405-413

Rosell D, Uriz MJ (1991) Cliona viridis (Schmidt, 1862) and Cliona nigricans (Schmidt, 1862) (Porifera, Hadromerida): evidence which shows they are the same species. Ophelia 33:45-53

Rowan R (2004) Coral bleaching. Thermal adaptation in reef coral symbionts. Nature 430:742

Rowan R, Powers D (1991) Molecular genetic identification of symbiotic dinoflagellates (zooxanthellae). Mar Ecol Prog Ser 71:65-73

Rützler K (1990) Associations between Caribbean sponges and photosynthetic organisms. In: Rützler K (ed) New perspectives in sponge biology. Smithsonian Institution Press, Washington DC, p 455-466

Rützler K (2002) Impact of crustose clionid sponges on Caribbean reef corals. Acta Geol Hispanica 37:61-72

Sammarco PW, Risk MJ, Rose C (1987) Effects of grazing and damselfish territoriality on internal bioerosion of dead corals: indirect effects. J Exp Mar Biol Ecol 112:185-199

Editorial responsibility: Charles Birkeland (Contributing Editor), Honolulu, Hawaii, USA
Sarà M, Liaci L (1964) Symbiotic associations between zooxanthellae and 2 marine sponges of the genus Cliona. Nature 203:321

Scalera-Liaci L, Sciscioli M, Lepore E, Gaino E (1999) Symbiotic zooxanthellae in Cinachyra tarentina, a non-boring demosponge. Endocytobiosis Cell Res 13:105-114

Schneider S, Roessli D, Excoffier L (2000) Arlequin ver. 2.000: A software for population genetics data analysis. Genetics and Biometry Laboratory, University of Geneva, Switzerland

Schönberg CHL (2000) Bioeroding sponges common to the central Australian Great Barrier Reef: description of 3 new species, 2 new records, and additions to 2 previously described species. Senckenb Marit 30:161-221

Schönberg CHL (2002) Sponges of the 'Cliona viridis complex' - a key for species identification. Proc 9th Int Coral Reef Symp 1:295-299

Schönberg CHL, Wilkinson CR (2001) Induced colonization of Great Barrier Reef corals by a clionid bioeroding sponge. Coral Reefs 20:69-76

Schwieger F, Tebbe CC (1998) A new approach to utilize PCR-single-strand-conformation polymorphism for $16 \mathrm{~S}$ rRNA gene-based microbial community analysis. Appl Env Microbiol 64:4870-4876

Sheffield VC, Beck JS, Kwitek AE, Sandstrom DW, Stone EM (1993) The sensitivity of single-strand conformational polymorphism analysis for the detection of single base substitutions. Genomics 16:325-332

Swofford, DL (2002) PAUP*. Phylogenetic analysis using parsimony ( ${ }^{*}$ and other methods) version 4.0b10. Sinauer Associates. Sunderland, MA

Thompson JD, Higgins DG, Gibson TJ (1994) CLUSTAL W: Improving the sensitivity of progressive multiple sequence alignment through sequence weighting, position-specific gap penalties and weight matrix choice. Nuc Acids Res 22: 4673-4680

Trench R (1997) Diversity of symbiotic dinoflagellates and the evolution of microalgal-invertebrate symbioses. In: Lessios H, MacIntyre I (eds) Proc 8th Int Coral Reef Symp Panama, 2:1275-1286

Vacelet J (1981) Algal-sponge symbioses in the coral reefs of New Caledonia: a morphological study. Proc 4th Int Coral Reef Symp 2:713-719

Vicente VP (1978) An ecological evaluation of the West Indian demosponge Anthosigmella varians (Hadromerida: Spirastrellidae). Bull Mar Sci 28:771-777

Vicente VP (1990) Response of sponges with autotrophic endosymbionts during the coral-bleaching episode in Puerto Rico. Coral Reefs 8:199-202

Warburton FE (1966) The behavior of sponge larvae. Ecology 47:672-674

Wilcox TP (1998) Large-subunit ribosomal RNA systematics of symbiotic dinoflagellates: morphology does not recapitulate phylogeny. Mol Phyl Evol 10:436-448

Submitted: November 24, 2004; Accepted: May 24, 2005

Proofs received from author(s): August 1, 2005 